\title{
Strategi Revitalisasi Kawasan Banten Lama
}

\author{
Aluh Shiba Hizmiakanza dan Dian Rahmawati \\ Jurusan Perencanaan Wilayah dan Kota, Fakultas Arsitektur, Desain dan Perencanaan \\ Institut Teknologi Sepuluh Nopember (ITS) \\ E-mail: d_rahmawati@urplan.its.ac.id
}

\begin{abstract}
Abstrak-Provinsi Banten memiliki Kawasan Strategis berupa Kawasan Banten Lama yang merupakan bagian dari Urban Heritage dimana kawasan tersebut mempunyai nilai sejarah yang sangat tinggi. Fenomena mengenai Kawasan Banten Lama saat ini mengalami penurunan dalam segi kualitas fisik dan fungsi kawasan. Turunnya vitalitas Kawasan Banten Lama menjadi salah satu ancaman dari kelestarian cagar budaya pada Provinsi Banten. Guna mempertahankan kawasan tersebut, upaya dari pemerintah adalah mengusung program revitalisasi pada Kawasan Banten Lama namun sampai saat ini belum terealisasikan. Maka dari itu, upaya dari penelitian ini adalah merumuskan strategi revitalisasi pada Kawasan Banten Lama. Penentuan faktor - faktor penyebab turunnya vitalitas kawasan dianalisa memakai metode Root-Cause Analysis dengan tools diagram sebab-akibat. Sedangkan, perumusan strategi revitalisasi dianalisa memakai metode SWOT Analysis dengan tools IFAS EFAS, Diagram Cartesius dan Matriks SWOT. Hasil dari Root-Cause Analysis berupa faktor - faktor yang ada memiliki keterkaitan satu sama dengan yang lain, hal ini terlihat dari faktor ekonomi, faktor fisik, serta faktor kebudayaan mempunyai akar permasalahan dari faktor sosial masyarakat dan faktor institusional. Sedangkan, hasil dari Analisis SWOT berupa Kawasan Banten Lama terletak pada kuadran IV dimana kondisi tersebut menggambarkan Kawasan Banten Lama tidak menguntungkan dengan di dominasi pada kelemahan dan ancaman. Strategi pertahanan merupakan kriteria yang paling cocok dalam strategi revitalisasi Kawasan Banten Lama.
\end{abstract}

Kata Kunci-Urban Heritage, Revitalisasi, Strategi.

\section{PENDAHULUAN}

K awasan Cagar Budaya atau yang dikenal sebagai Kawasan Urban Haritage merupakan kawasan yang pernah menjadi pusat - pusat dari kompleksitas fungsi kegiatan ekonomi, sosial dan budaya yang mengakumulasikan makna kesejarahan (historical cultural)[1]. Provinsi Banten yang terletak di bagian barat Pulau Jawa ini memiliki kawasan dengan nilai historis yang sangat tinggi yaitu Kawasan Banten Lama. Kawasan tersebut merupakan cagar budaya perkotaan yang terletak di Kota Serang. Hal ini menjadikan kawasan tersebut dijuluki dengan sebutan urban heritage. Kawasan tersebut merupakan bagian dari cerita sejarah pembentukan Provinsi Banten dan juga kawasan tersebut merupakan sisa kejayaan Kerajaan Kesultanan Islam Banten sejak tahun 1.500. Kawasan Banten Lama sangat berperan penting dalam memacu perkembangan daerahnya, pada saat itu keberadaan Banten Lama merupakan pertumbuhan kota dan pusat kegiatan perekonomian yang terkonsentrasi di sekitar Kawasan Banten Lama. Peta Kawasan Banten Lama Bisa dilihat pada Gambar 1. Kawasan Banten Lama ditetapkan sebagai Kawasan Strategis Provinsi dari sudut kepentingan sosial dan budaya dan diperuntukan untuk kawasan wisata[2]. Fenomena mengenai kondisi Kawasan Banten Lama mulai tak tersentuh pelestariannya.



Gambar 1. Peta Kawasan Banten Lama

Perkembangan kawasan semakin hari semakin membuat makna kawasan semakin luntur dan membuat objek Kawasan Banten Lama yang bersejarah tersebut menjadi terpuruk dan tidak atraktif. Sehingga, Kawasan Banten Lama mengalami penurunan kualitas fisik dan fungsi kawasan. Kawasan Banten Lama beralih fungsi menjadi tempat permukiman kumuh serta tumbuhnya sektor pedagang informal pada sekitar kawasan. Selain itu, terlihat juga ketidakserasian fungsi dalam Kawasan Banten Lama seperti Keraton Surosowan dan Benten Spellwijk yang diakibatkan oleh adanya sector informal serta dijadikannya tempat bermain bola dalam bangunan cagar budaya tersebut. Kawasan Banten Lama juga terlihat mengalami kemunduran dari segi fisik. Hal tersebut antara lain terlihat dari kondisi jalan yang tidak terawat serta berlubang, kurangnya perawatan dan penataan kawasan, tidak adanya penataan sirkulasi kendaraan, tidak adanya RTH di sekitar objek penelitian, kurangnya optimalisasi fungsi tempat parkir serta tidak adanya fasilitas air bersih dan persampahan. Sebagai kawasan yang diperuntukan pariwisata, jumlah pengunjung wisata pada Kawasan Banten Lama mengalami peningkatan setiap tahunnya. Hal ini menjadi ancaman bagi heritage yang berada didalamnya. Wisatawan yang berkunjung tidak turut menjaga kelestarian heritage pada Kawasan Banten Lama[3].

Kondisi - kondisi tersebut jika dibiarkan akan menjadi ancaman sendiri bagi kelestarian cagar budaya pada Kawasan Banten Lama. Salah bentuk memperbaiki kawasan tersebut adalah dengan revitalisasi. Revitalisasi merupakan serangkaian upaya menghidupkan kembali kawasan yang cenderung mati, meningkatkan nilai - nilai vitalitas yang strategis dan signifikan dari kawasan yang mempunyai potensi atau mengendalikan kawasan yang cenderung kacau [4]. Revitalisasi pada Kawasan Banten Lama merupakan program yang diusungkan oleh Dinas Pariwisata Provinsi Banten namun hingga kini, bentuk realisasinya belum berjalan sejak tahun 2014. Program ini juga telah mendapat dukungan dari Dinas Pekerjaan Umum dan Penataan Ruang Provinsi Banten berupa rencana pembentukan Masterplan 
Revitalisasi Kawasan Banten Lama[5]. Tujuan dari program tersebut adalah meningkatkan vitalitas suatu kawasan guna mempertahankan nilai kesejarahan yang terdapat pada Kawasan Banten Lama.

Dengan demikian, program revitalisasi yang diusung oleh Dinas Pariwisata Provinsi Banten perlu segera direalisasikan. Hingga kini, Dinas Pariwisata Provinsi Banten belum memiliki arahan yang cukup untuk merealisasikan program revitalisasi yang dimaksud. Oleh karena itu, peneliti menyusun penelitian ini sebagai riset untuk mendukung terealisasinya program revitalisasi tersebut. Penelitian ini juga berguna melihat melihat akar - akar permasalahan dari menurunnya fungsi kawasan dan strategi untuk mengembalikan vitalitas Kawasan Banten Lama dan diharapkan dapat dijadikan kajian untuk program revitalisasi kedepannya.

\section{METODE PENELITIAN}

Pendekatan yang digunakan pada penelitian ini adalah rasionalistik. Pendekatan rasionalistik merupakan sebuah pendekatan yang bersumber dari teori dan kebenaran empirik[6]. Penelitian ini berjenis kualitatif bersifat deskriptif preskriptif yang merujuk kepada penelitian quasi qualitative. Penelitian ini dimaksudkan untuk mencari turunnya vitalitas dan untuk merumuskan strategi revitalisasi pada Kawasan Banten Lama. Data pada penelitian ini didapatkan dengan melakukan wawancara kepada stakeholder yang ditentukan melalui purposive sampling dengan melakukan stakeholder analysis. Purposive sampling didapat secara in-depth interview. Wawancara dilakukan pada stakeholders yang terlibat dan berpengaruh pada Kawasan Banten Lama, sehingga proses dalam menggali faktor yang berpengaruh terhadap Kawasan Banten Lama dapat sesuai.

\section{A. Stakeholder Analysis}

Analisis stakeholder yang dilakukan mengambil beberapa kelompok stakeholder diantaranya kelompok pemerintah, masyarakat dan swasta. Hal ini diawali dengan melihat tugas pokok dari masing - masing stakeholders. Kemudian identifikasi terhadap menurut tingkat kepentingan dan pengaruh dalam revitalisasi pada Kawasan Banten Lama yang dapat dilihat pada Tabel 1.

\section{B. Purposive Sampling}

Teknik sampling purposive diharapkan dapat memberikan sampel penelitian yang representative pada penelitian ini, yang mana hal tersebut termasuk pembuatan kriteria sebagai syarat yang diharapkan mencapai tujuan penelitian yang diinginkan.

Tabel 1.

Stakeholders pada Penelitian

\begin{tabular}{|c|c|c|}
\hline Stakeholders & Posisi Stakeholders & Alasan Pemilihan \\
\hline \multirow[t]{10}{*}{ Pemerintah } & $\begin{array}{l}\text { Badan Perencanaan Pembangunan Daerah } \\
\text { Provinsi Banten }\end{array}$ & $\begin{array}{l}\text { - Pembuat Kebijakan } \\
\text { - Mempunyai kepentingan dalam proses pelaksanaan program revitalisasi pada } \\
\text { kawasan }\end{array}$ \\
\hline & Dinas Pariwisata Provinsi Banten & Dinas pelaksana program revitalisasi pada kawasan \\
\hline & $\begin{array}{l}\text { Dinas Pekerjaan Umum dan Penataan Ruang } \\
\text { Provinsi Banten }\end{array}$ & $\begin{array}{l}\text { Pelaksana teknis yang berpengaruh terhadap keberlangsungan program revitalisasi } \\
\text { pada kawasan. }\end{array}$ \\
\hline & $\begin{array}{l}\text { Badan Perencanaan Pembangunan Daerah Kota } \\
\text { Serang }\end{array}$ & $\begin{array}{l}\text { Pembuatan kebijakan Mempunyai kepentingan dalam proses pelaksanaan program } \\
\text { revitalisasi pada kawasan. }\end{array}$ \\
\hline & Dinas Pariwisata Kota Serang & Kawasan merupakan peruntukan wisata \\
\hline & $\begin{array}{l}\text { Dinas Pekerjaan Umum dan Penataan Ruang } \\
\text { Kota Serang }\end{array}$ & $\begin{array}{l}\text { Pelaksana teknis yang berpengaruh terhadap keberlangsungan program revitalisasi } \\
\text { kawasan. }\end{array}$ \\
\hline & Balai Pelestarian Cagar Budaya Serang & $\begin{array}{l}\text { - Badan yang melindungi, melestarikan, mengawasi } \\
\text { - Mengendalikan kawasan cagar budaya dalam keberlangsungan program } \\
\text { revitalisasi }\end{array}$ \\
\hline & Museum Situs Kepurbakalaan Banten Lama & $\begin{array}{l}\text { - Badan yang melestarikan objek wisata } \\
\text { - Memahami kawasan cagar budaya pada kawasan }\end{array}$ \\
\hline & Kecamatan Kasemen & Peran penting dalam lapisan masyarakat pada kawasan \\
\hline & Kelurahan Banten & Peran penting dalam lapisan masyarakat pada kawasan \\
\hline Masyarakat & Tokoh Kenadzira Banten Lama & Pihak penting dalam lapisan masyarakat Kawasan Banten Lama. \\
\hline
\end{tabular}

Tabel 2

Kriteria Pemilihan pada setiap stakeholders

\begin{tabular}{lll}
\hline \hline Stakeholders & \multicolumn{1}{c}{ Posisi Stakeholders } & \multicolumn{1}{c}{ Kriteria Pemilihan } \\
\hline Pemerintah & Badan Perencanaan Pembangunan Daerah Provinsi Banten & $\bullet$ Pria/Wanita \\
& Dinas Pariwisata Provinsi Banten & $\bullet$ Usia $25-55$ tahun \\
& Dinas Pekerjaan Umum dan Penataan Ruang Provinsi Banten & $\bullet$ Pendidikan minimal SMA \\
& Badan Perencanaan Pembangunan Daerah Kota Serang & $\bullet$ Mengetahui Program Revitalisasi pada Kawasan Banten Lama \\
& Dinas Pariwisata Kota Serang & $\bullet$ Mempunyai keterlibatan pada program revitalisasi \\
& Dinas Pekerjaan Umum dan Penataan Ruang Kota Serang & \\
& Balai Pelestarian Cagar Budaya Serang & \\
& Museum Situs Kepurbakalaan Banten Lama & \\
& Kecamatan Kasemen & \\
& Kelurahan Banten & • Pria/Wanita \\
& Tokoh Kenadziran Banten Lama & Usia 25 - 55 tahun \\
& & Pendidikan minimal SMA \\
& & Mengetahui Program Revitalisasi pada Kawasan Banten Lama \\
& & Bempunyai keterlibatan pada program revitalisasi pada Kawasan \\
\hline \hline
\end{tabular}




\section{Variabel Penelitian}

Variabel penelitian digunakan untuk mengidentifikasi faktor - faktor yang menyebabkan penurunan vitalitas pada Kawasan Banten Lama dapat dilihat pada Tabel 3.

Tabel 3.

Variabel Penelitian

\begin{tabular}{ll}
\hline \hline Indikator & Variabel \\
\hline Kondisi Kawasan & • Kondisi Bangunan Cagar Budaya \\
& • Sarana Penunjang Kawasan \\
& - Sirkulasi Kawasan \\
& • Sarana Transportasi \\
& • Kondisi Kebudayaan Kawasan \\
& • Kondisi Sosial Kawasan \\
& • Kondisi Ekonomi Kawasan \\
\hline Institusional & - Kebijakan Kawasan \\
& • Institusi yang Terlibat \\
\hline \hline
\end{tabular}

\section{Teknik Analisis Data}

Data pada penelitian ini diolah dengan Root Cause Analysis serta SWOT Analysis. Root Cause Analysis (RCA) adalah sebuah tools yang didesain untuk memahami akar penyebab permasalahan sebuah peristiwa didasarkan pada kausalitas dalam sebuah proses[7]. Root Cause Analysis dipilih untuk mengetahui akar permasalahan pada Kawasan Banten Lama, analisis ini menggunakan wawancara kepada stakeholders yang telah ditentukan. Root Cause Analysis dilakukan dengan beberapa tahapan antara lain: inventarisasi data, penyusunan diagram sebab - akibat atau fishbone diagrams, analisa penyebab akar permasalahan, dan penyusunan rekomendasi. Secara proses, tujuan utama dari RCA adalah mengidentifikasi dan memahami "apa, bagaimana, dan mengapa” pada sebuah peristiwa untuk kemudian dirumuskan strategi yang tepat dalam penanganan permasalahan terkait "error" yang ditemukan dalam proses analisa[8].

Setelah itu merumuskan strategi revitalisasi menggunakan alat analisis SWOT Analysis. SWOT Analysis digunakan untuk mengetahui kekuatan dan kelemahan pada faktor internal serta peluang dan ancaman pada faktor eksternal. Hal tersebut sebagai dasar untuk strategi dalam rencana program revitalisasi di Kawasan Banten Lama. Dengan menggunakan teknik tersebut diupayakan untuk mengoptimumkan kekuatan dari dalam dan peluang dari luar serta meminimumkan kelemahan dari dalam dan tantangan atau ancaman yang datang dari luar. Langkah dalam analisa SWOT berupa pengumpulan data, pengelompokan Internal Factors Analysis Summary (IFAS) dan Eksternal Factors Analysis Summary (EFAS), Diagram Cartesius SWOT, penyusunan matriks SWOT dan penyusunan strategi yang sesuai[9].

\section{HASIL DAN DISKUSI}

Menurunnya vitalitas pada Kawasan Banten lama dipengaruhi oleh berbagai faktor. Faktor tersebut diidentifikasi melalui wawancara kepada stakeholders. Faktor yang teridentifikasi merupakan permasalahan dari faktor yang menyebabkan kondisi Kawasan Banten Lama menurun vitalitasnya. Berikut adalah penjabaran hasil analisis faktor yang mempengaruhi penurunan vitalitas pada Kawasan Banten Lama.

\section{Faktor Fisik}

Faktor fisik ini memiliki sub-faktor yang merupakan variabel pada penelitian yaitu terdiri dari kondisi bangunan cagar budaya, sarana penunjang kawasan, sirkulasi kawasan dan sarana transportasi.

1) Kondisi Bangunan Cagar Budaya

Bangunan cagar budaya pada Kawasan Banten Lama pada penelitian ini diartikan sebagai bangunan heritage yang berada pada Kawasan Banten Lama yang mengalami kerusakan. Bangunan cagar budaya tersebut merupakan salah satu atraksi utama pada Kawasan Banten Lama. Berdasarkan hasil Root Cause Analysis dengan memakai Diagram SebabAkibat atau yang disebut juga Fishbone Diagrams, permasalahan utama pada kondisi bangunan cagar budaya adalah kondisi yang tidak terawat serta rusaknya bangunan cagar budaya dana adanya penuaan pada bangunan cagar budaya. Permasalahan tersebut akan dijabarkan lagi sampai pada akar permasalahan. Akar permasalahan dari variabel kondisi bangunan cagar budaya dapat dilihat dari Gambar 2 bagan dibawah ini.



Gambar 2. Diagram Sebab - Akibat Variabel Kondisi Bangunan Cagar Budaya

\section{2) Sarana Penunjang Kawasan}

Sarana penunjang pada Kawasan Banten Lama pada penelitian ini diartikan sebagai sarana dan prasarana penunjang yang berada pada Kawasan Banten Lama. Sarana penunjang sangat dibutuhkan pada Kawasan Banten Lama dikarenakan kawasan tersebut diperuntukan sebagai wisata. Sarana penunjang sangat dibutuhkan pada Kawasan Banten Lama. Berdasarkan hasil Root Cause Analysis dengan memakai Diagram Sebab-Akibat, permasalahan utama pada sarana penunjang kawasan adalah sarana penunjang yang sudah ada belum bisa memenuhi aktivitas yang berada di Kawasan Banten Lama dan sarana masih belum tersedia seperti tidak tersedianya sentral parkir, belum tersedianya kios resmi dan belum tersedianya pusat informasi kawasan. Permasalahan tersebut akan dijabarkan lagi sampai pada akar permasalahan. Akar permasalahan dari variabel sarana penunjang kawasan dapat dilihat dari Gambar 3 bagan dibawah ini. 


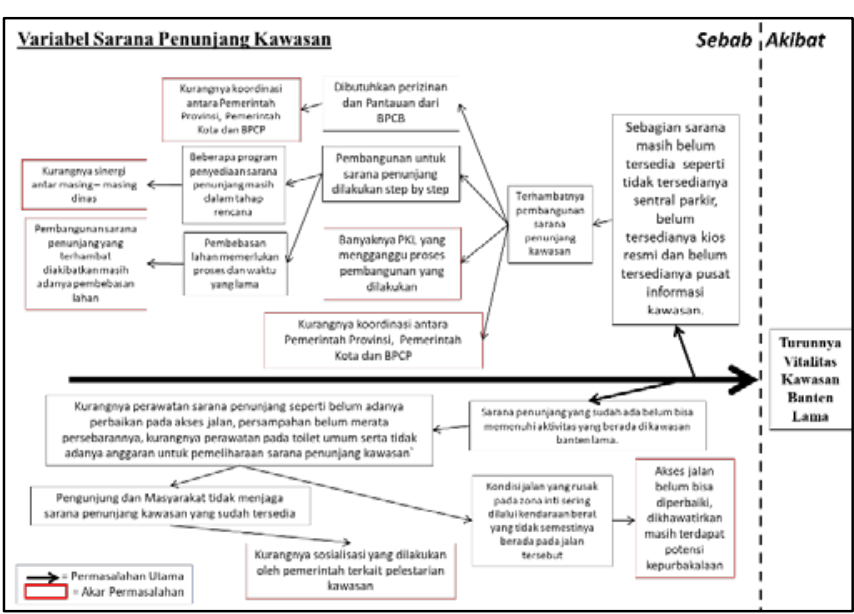

Gambar 3. Diagram Sebab - Akibat Variabel Sarana Penunjang Kawasan

\section{3) Sirkulasi Kawasan}

Sirkulasi kawasan pada Kawasan Banten Lama pada penelitian ini diartikan sebagai pola pergerakan yang menghubungkan bangunan heritage satu dengan bangunan yang lainnya. Sirkulasi pada Kawasan Banten Lama sangat penting, mengingat kawasan tersebut diperuntukan sebagai kawasan wisata. Berdasarkan hasil Root Cause Analysis dengan memakai Diagram Sebab-Akibat, permasalahan utama pada kondisi sirkulasi pada Kawasan Banten Lama adalah sirkulasi kawasan yang tidak terkoneksi satu sama lain. Permasalahan tersebut akan dijabarkan lagi sampai pada akar permasalahan. Akar permasalahan dari variabel kondisi sirkulasi kawasan dapat dilihat dari Gambar 4 bagan dibawah ini.

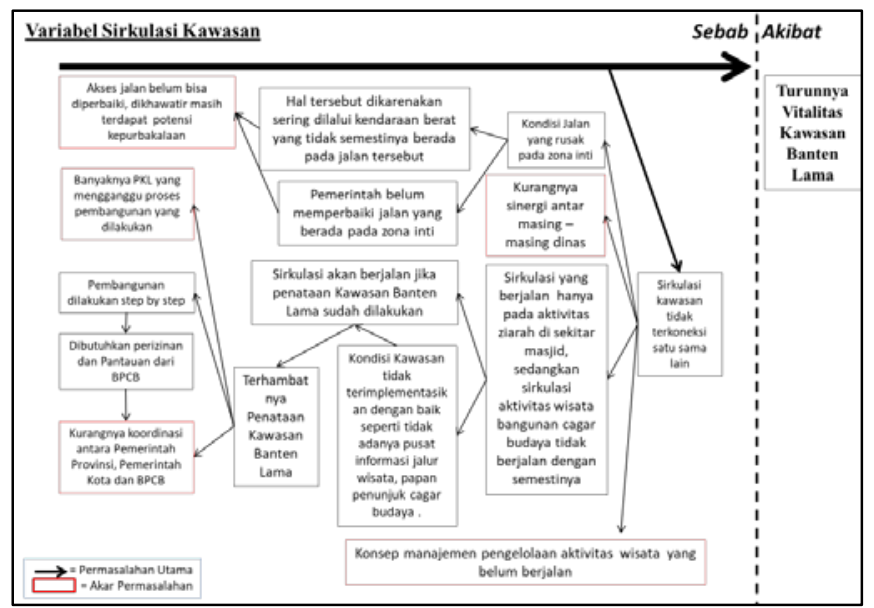

Gambar 4.Diagram Sebab - Akibat Variabel Sirkulasi Kawasan

\section{1) Sarana Transportasi}

Sarana Transportasi pada Kawasan Banten Lama pada penelitian ini diartikan sebagai sarana transportasi atau moda transportasi yang tersedia pada Kawasan Banten Lama. Sarana transportasi sangat dibutuhkan sebagai moda untuk berpindah dari suatu tempat ke tempat yang lain, hal ini sangat dibutuhkan pada Kawasan Banten Lama mengingat kawasan wisata yang mempunyai luas lahan kurang lebih 15 Ha. Berdasarkan hasil Root Cause Analysis dengan memakai Diagram Sebab-Akibat, permasalahan utama pada kondisi sarana transportasi pada Kawasan Banten Lama adalah moda transportasi terbatas hanya mempunyai tujuan yang mengarah pada kawasan sudah tidak ada penggunanya lagi dan moda yang belum tersedia menyeluruh pada Kawasan Banten Lama. Permasalahan tersebut akan dijabarkan lagi sampai pada akar permasalahan. Akar permasalahan dari variabel kondisi sarana transportasi dapat dilihat dari Gambar 5 bagan dibawah ini.

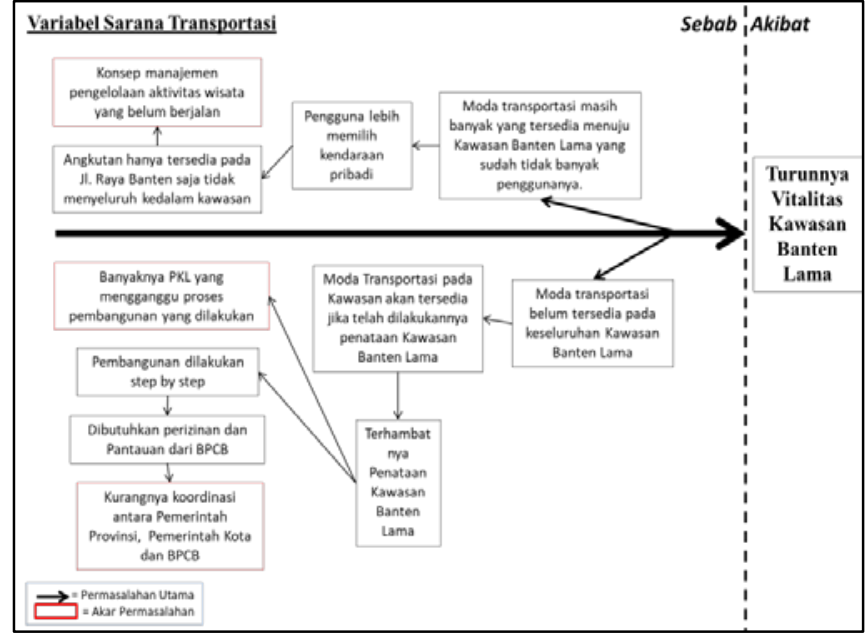

Gambar 5. Diagram Sebab - Akibat Variabel Sarana Transportasi

\section{Faktor Budaya}

Faktor Budaya ini memiliki sub-faktor yang merupakan variabel pada penelitian yaitu kondisi kebudayaan kawasan. Kebudayaan Kawasan Banten Lama pada penelitian ini diartikan sebagai kondisi kebudayaan/ kesenian/ event budaya yang menjadi tradisi lokal masyarakat setempat dan merupakan daya pikat utama / daya tarik heritage pada Kawasan Banten Lama. Kebudayaan pada Kawasan Banten Lama patut dilestarikan mengingat kawasan mempunyai history value yang tinggi pada nilai kesejarahan. Berdasarkan hasil Root Cause Analysis dengan memakai Diagram SebabAkibat, permasalahan utama pada kondisi kebudayaan pada Kawasan Banten Lama adalah kultur kebudayaan serta event kebudayaan yang mulai menghilang dari Kawasan Banten Lama dan keterlibatan masyarakat terhadap kebudayaan yang sudah mengalami penurunan. Permasalahan tersebut akan dijabarkan lagi sampai pada akar permasalahan.. Akar permasalahan dari variabel kondisi sarana transportasi dapat dilihat dari Gambar 6 bagan dibawah ini.

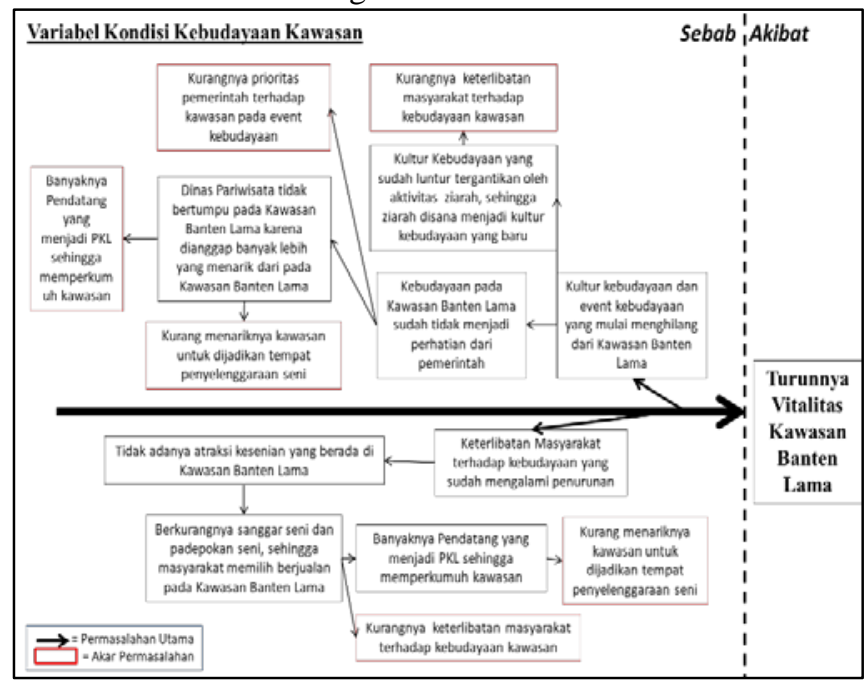

Gambar 6. Diagram Sebab - Akibat Variabel Kondisi Kebudayaan Kawasan

\section{Faktor Sosial}

Faktor Sosial ini memiliki sub-faktor yang merupakan variabel pada penelitian yaitu kondisi sosial kawasan. Kondisi sosial Kawasan Banten Lama pada penelitian ini diartikan sebagai kondisi kegiatan sosial atau tata cara hidup dari masyarakat yang berada pada Kawasan Banten Lama. Kondisi sosial dalam masyarakat Kawasan Banten Lama mempunyai banyak permasalahan yang kompleks hal ini 
membuat heritage pada Kawasan Banten Lama terancam. Berdasarkan hasil Root Cause Analysis dengan memakai Diagram Sebab-Akibat, permasalahan utama pada kondisi sosial masyarakat pada Kawasan Banten Lama adalah banyaknya pendatang, munculnya para pedagang kaki lima dan banyaknya konflik sosial. Permasalahan tersebut akan dijabarkan lagi sampai pada akar permasalahan. Akar permasalahan dari variabel kondisi sosial kawasan dapat dilihat dari Gambar 7 bagan dibawah ini.

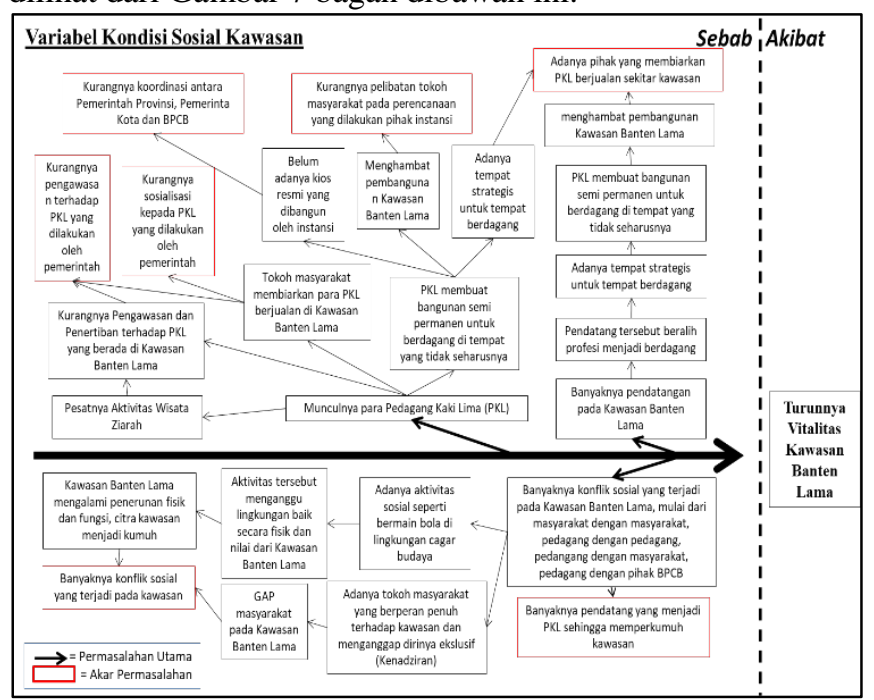

Gambar 7. Diagram Sebab - Akibat Variabel Kondisi Sosial Kawasan

\section{Faktor Ekonomi}

Faktor Ekonomi ini memiliki sub-faktor yang merupakan variabel pada penelitian yaitu Kondisi Ekonomi Kawasan. Kondisi ekonomi Kawasan Banten Lama pada penelitian ini diartikan sebagai kondisi yang mendeskripsikan kegiatan perekonomian yang berada pada Kawasan Banten Lama. Perekonomian pada suatu kawasan berguna untuk menambah pendapatan asli daerah serta untuk biaya perawatan kawasan itu sendiri. Berdasarkan hasil Root Cause Analysis dengan memakai Diagram Sebab-Akibat, permasalahan utama pada kondisi sosial masyarakat pada Kawasan Banten Lama adalah kawasan banten lama tidak memberikan pemasukan untuk daerah dan berdagang (informal) menjadi ekonomi yang paling dominan dalam Kawasan Banten Lama. Permasalahan tersebut akan dijabarkan lagi sampai pada akar permasalahan. Akar permasalahan dari variabel kondisi ekonomi kawasan dapat dilihat dari Gambar 8 bagan dibawah ini.

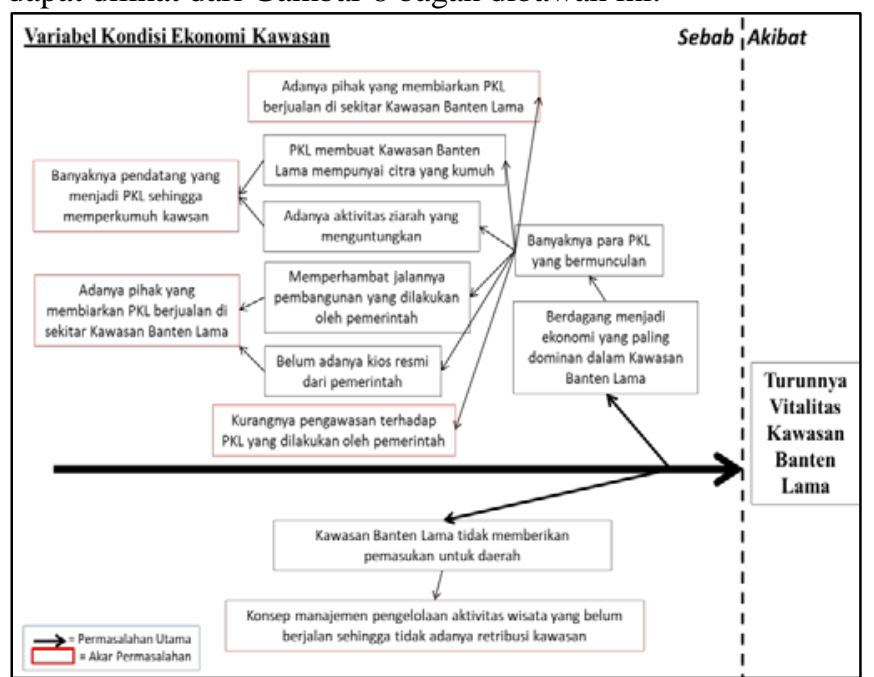

Gambar 8. Diagram Sebab - Akibat Variabel Kondisi Ekonomi Kawasan

\section{E. Faktor Institusi}

Faktor Institusi ini memiliki sub-faktor yang merupakan variabel pada penelitian yaitu kebijakan kawasan dan institusi yang terlibat. Kebijakan kawasan dalam penelitian ini diartikan sebagai aturan/ regulasi/ kebijakan yang mengatur segala kegiatan yang berada pada Kawasan Banten Lama. Sedangkan institusi yang terlibat diartikan pada penelitian ini sebagai institusi kelembagaan yang ikut terlibat segala aktivitas yang berada pada Kawasan Banten Lama. Kedua hal tersebut sangat penting bagi suatu kawasan terlebih pada Kawasan Banten Lama tidak lain untuk kawasan tidak terjadi tumpang tindih dikarenakan banyaknya kepentingan baik secara individu, kelompok, instansi maupun kelembagaan pada kawasan tersebut. Berdasarkan hasil Root Cause Analysis dengan memakai Diagram Sebab-Akibat, permasalahan utama pada faktor institusi pada Kawasan Banten Lama adalah regulasi yang ada hanya terpatok pada UU Cagar Budaya yang mana kurang terimplementasikan dengan baik, peraturan yang mengatur kawasan belum ada, kurangnya koordinasi yang terjadi antara Pemerintah Provinsi, Pemerintah Kota dan BPCB, Kurangnya sinergi dari masing - masing dinas yang terlibat, Kurangnya pelibatan tokoh masyarakat pada perencanaan pembangunan yang dilakukan pihak instansi serta Banyaknya kepentingan individu/ kelompok/ instansi/ kelembagaan pada Kawasan Banten Lama. Permasalahan tersebut akan dijabarkan lagi sampai pada akar permasalahan. Akar permasalahan dari variabel institusi yang terlibat serta kebijakan kawasan dapat dilihat dari Gambar 9 bagan dibawah ini.

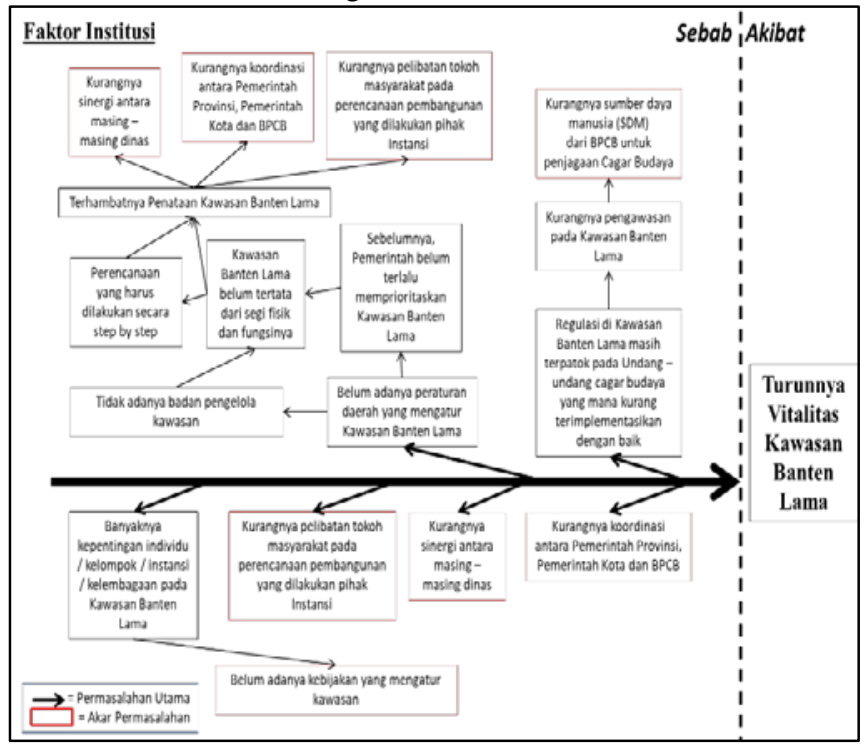

Gambar 9. Diagram Sebab - Akibat Variabel Kebijakan Kawasan dan Institusi yang Terlibat

Bedasarkan hasil kesuluruhan diagram sebab-akibat pada Root Cause Analisis didapatkan akar permasalahan yang menyebabkan turunnya vitalitas Kawasan Banten Lama, dapat dilihat pada Tabel 4.

Tabel 4.

Akar Permasalahan dari Setiap Faktor

\begin{tabular}{cl}
\hline \hline Faktor & \multicolumn{1}{c}{ Penjelasan } \\
\hline & $\begin{array}{l}\text { 1. Kurangnya SDM dari pihak BPCB untuk penjagaan } \\
\text { bangunan cagar budaya }\end{array}$ \\
& $\begin{array}{l}\text { 2. Akses jalan belum bisa diperbaiki, dikhawatirkan masih } \\
\text { terdapat potensi kepurbakalaan }\end{array}$ \\
& $\begin{array}{l}\text { 3. Konsep manajemen pengelolaan aktivitas wisata yang } \\
\text { belum berjalan }\end{array}$ \\
& 4. Kurangnya sinergi antar masing - masing dinas
\end{tabular}


5. Banyaknya PKL yang mengganggu proses pembangunan yang dilakukan

6. Kurangnya sosialisasi yang dilakukan oleh pemerintah terkait pelestarian kawasan

7. Kurangnya koordinasi antara Pemerintah Provinsi, Pemerintah Kota dan BPCB

8. Pembangunan sarana penunjang yang terhambat diakibatkan masih adanya pembebasan lahan

1. Kurangnya prioritas Pemerintah terhadap kawasan pada event kebudayaan

2. Kurangnya keterlibatan masyarakat terhadap kebudayaan

Kebudayaan 3. Banyaknya pendatang yang menjadi PKL sehingga memperkumuh kawasan

4. Kurang menariknya kawasan untuk dijadikan tempat penyelenggaraan seni

1. Banyaknya konflik sosial yang terjadi pada kawasan

2. Banyaknya pendatang yang menjadi PKL sehingga memperkumuh kawasan

3. Kurangnya sosialisasi kepada PKL yang dilakukan oleh pemerintah

4. Adanya pihak yang membiarkan PKL bejualan sekitar kawasan

5. Kurangnya pengawasan terhadap PKL yang dilakukan oleh Pemerintah

6. Kurangnya koordinasi antara Pemerintah Provinsi, Pemerintah Kota dan BPCB

7. Kurangnya pelibatan tokoh masyarakat pada perencanaan yang dilakukan pihak instansi

1. Banyaknya pendatang yang menjadi PKL sehingga memperkumuh kawasan

2. Konsep manajemen pengelolaan aktivitas wisata yang belum berjalan sehingga tidak adanya retribusi kawasan

Ekonomi 3. Kurangnya pengawasan terhadap PKL yang dilakukan oleh Pemerintah

4. Adanya pihak yang membiarkan PKL bejualan sekitar kawasan

1. Kurangnya SDM dari pihak BPCB untuk penjagaan bangunan cagar budaya

2. Kurangnya pelibatan tokoh masyarakat pada perencanaan yang dilakukan pihak instansi

Institusional 3. Kurangnya koordinasi antara Pemerintah Provinsi, Pemerintah Kota dan BPCB

4. Kurangnya sinergi antar masing - masing dinas

5. Belum adanya kebijakan yang mengatur Kawasan Banten Lama

Akar permasalahan tersebut dijadikan input untuk analisis selanjutnya untuk merumuskan strategi revitalisasi Kawasan Banten Lama dengan menggunakan metode SWOT Analysis. Akar permasalahan yang sudah didapat dikelompokan menjadi faktor internal serta faktor eksternal untuk mengetahui strength, weakness, opportunity dan threat. Setelah itu dilakukan pembobotan serta rating melalui kuesioner rating IFAS dan EFAS. Bobot tersebut dilihat untuk penilaian kondisi saat ini sedangkan rating dipakai untuk menilai urgensi penanganan terhadap faktor yang ada [9]. Berdasarkan hasil pembobotan dan rating tersebut didapat faktor kekuatan memliki total sebesar 1.363, faktor kelemahan memiliki total sebesar -2.032, faktor peluang memiliki total sebesar 1.274 dan faktor ancaman memiliki total sebesar -2.249. Hal tersebut diperoleh untuk penentuan koordinat objek yang diteliti pada diagram cartesius. Diagram Cartesius bertujuan untuk memperoleh strategi yang tepat dalam merevitalisasi Kawasan Banten Lama. Hasil penentuan koordinat Diagram Cartesius SWOT adalah sebagai berikut:

- Koordinat (x) : score strength + weakness $(\mathrm{x})=1.363+(-2.032)=-0.670$

- Koordinat (y) : score opportunity + threat $(\mathrm{y})=1.274+(-2.249)=-0.976$

Koordinat $(x, y)=(-0.670,-0.976)$
Koordinat tersebut menunjukan bahwa hasil IFAS dan EFAS terletak pada kuadran IV, berikut adalah letak posisi strategi pada Diagram Cartesius SWOT pada Gambar 10.

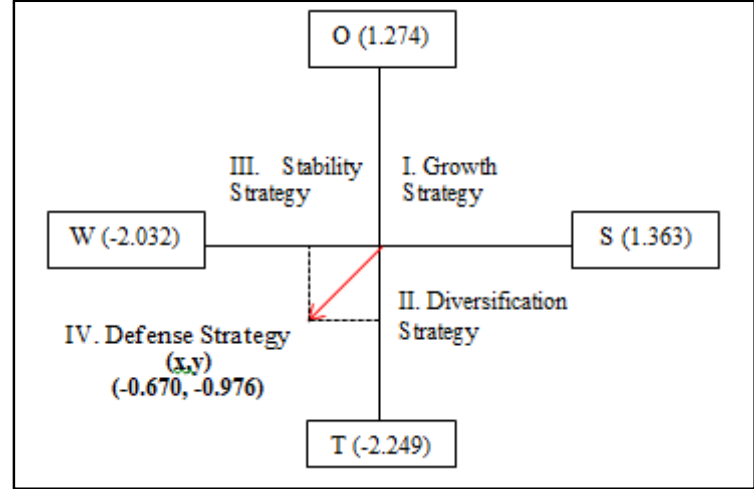

Gambar 10. Posisi Strategi pada Diagram Cartesius SWOT

Hasil tersebut menunjukan bahwa strategi utama / yang diprioritaskan pada kawasan penelitian merupakan Defense Strategy. Posisi tersebut merupakan situasi yang sangat tidak menguntungkan yang menandakan objek penelitian menghadapi kondisi yang lemah dan mempunyai tantangan besar. Kawasan Banten Lama dihadapkan dengan berbagai ancaman dan kelemahan internal. Dalam menentukan formulasi strategi, langkah selanjutnya ialah membuat Matriks SWOT yang mana merupakan alat penyusunan strategi untuk program pengembangan suatu kawasan. Penyusunan matriks tersebut merupakan persilangan dari strength - opportunity, weakness - opportunity, strength threat dan weakness - threat. Pada Kawasan Banten Lama, strategi yang dipakai ialah persilangan dari weakness dan threat. Hal ini dikarenakan posisi Kawasan Banten Lama pada Diagram Cartesius terletak pada kuadran IV. Berikut 7 alternatif strategi yang disusun untuk diterapkan dalam upaya revitalisasi pada Kawasan Banten Lama:

1) Menjalin kerjasama yang baik antara tokoh masyarakat, pihak pedagang (PKL) dengan pemerintah dalam pengimplementasian kebijakan / rencama pemeritah dalam hal revitalisasi kawasan.

Hal ini dilakukan agar tidak adanya ketimpangan pemangku kepentingan pada Kawasan Banten Lama. Para PKL juga harus dilibatkan kerjasama dalam penataan pada kawasan. Kerjasama tersebut bisa dalam hal relokasi pedagang untuk pembangunan sentra kuliner, pembangunan tersebut merupakan salah satu bentuk rencana dalam revitalisasi kawasan.

2) Membuat arahan kerja yang lebih teknis mengenai rencana program revitalisasi kawasan dengan pelibatan kepentingan instansi serta masyarakat yang berperan.

Hal ini dilakukan untuk memperbaiki kondisi koordinasi antar dinas serta sinergi antar pemerintah kota, pemerintah provinsi hingga BPCB selaku pelestarian bangunan cagar budaya. Sehingga dengan adanya pelibatan pemangku kepentingan tersebut, dalam proses pembangunan tidak akan adanya tumpang tindih.

3) Mengadakan pelatihan edukasi dan penyuluhan kepada masyarakat dalam hal nilai - nilai kesejarahan serta keterampilan atraksi yang mengandung nilai - nilai kebudayaan untuk lebih berperan aktif terhadap kawasan sehingga meningkatkan perekonomian Kawasan Banten Lama.

Pelatihan dan penyuluhan tentang kebudayaan kawasan tersebut dilakukan melalui fungsi para pemangku adat kesultanan banten yang sekarang dikenal dengan tokoh kenadziran. Dengan adanya lembaga adat tersebut, bertujuan 
untuk mempertahankan dan menanamkan kembali nilai nilai kebudayaan pada generasi muda serta melatih untuk lebih aktif dan kreatif dalam usaha memvitalkan kembali Kawasan Banten Lama dan diharapkan juga meningkatkan perekonomian kawasan tersebut.

4) Melakukan sosialisasi kepada para PKL dan masyarakat sebagai salah satu bentuk upaya pelestarian lingkungan dan fisik pada kawasan bersejarah.

Potensi pada kawasan akan berjalan dengan maksimal jika para pedagang PKL tidak memperkumuh kawasan. Maka dari itu, perlu adanya sosialisasi kepada para PKL dan masyarakat sekitar yang merupakan masyarakat awam untuk lebih sadar dan mengerti terhadap upaya pelestarian lingkungan kawasan serta fisik bangunan cagar budaya. Hal ini juga untuk membantu mempermudah jalannya program revitalisasi yang akan dilaksanakan.

5) Melakukan pemberdayaan masyarakat dan para PKL yang terdapat kawasan dalam perlibatan potensi sosial, ekonomi serta kebudayaan masyarakat lokal dalam pengelolaan aktivitas pada Kawasan Banten Lama.

Kawasan Banten Lama merupakan kawasan cagar budaya perkotaan yang diperuntukan untuk wiasata. Hal tesebut akan berjalan dengan baik jika dilakukan pemberdayaan masyarakat serta para pedagang PKL untuk pengelolaan secara maksimal dalam Kawasan Banten Lama seperti memberi kesempatan kepada masyarakat untuk menjadi tour guide, memberi peluang bagi pedagang untuk menjadi UKM yang lebih kreatif dalam menarik minat beli wisatawan dan menjadikan masyarakat lebih berpartisipasi dalam hal atraksi atau event kebudayaan pada Kawasan Banten Lama. Upaya tersebut juga untuk memaksimalkan potensi dari masyarakat yang ada, mempertahankan vitalitas kawasan serta membuat lapangan kerja baru bagi masyarakat lokal kawasan. Dengan adanya hubungan yang menguntungkan ini, masyarakat dapat lebih berpartisipasi terhadap program revitaliasi yang akan dilaksanakan.

6) Membuat kebijakan atau perangkat hukum yang sah untuk mengatur kawasan dalam upaya menunjang kelestarian kawasan serta mengadakan pengawasan rutin terhadap para PKL dan wisatawan yang berada pada kawasan.

Dengan penetapannya Kawasan Banten Lama sebagai kawasan cagar budaya berdasarkan Perda No. 2 Tahun 2011 Provinsi Banten, Kawasan Banten Lama seharusnya mendapat perlindungan secara khusus dan juga mendapat pengawasan yang mengatur masyarakat, wisatawan serta para PKL yang berada dekat dengan situs cagar budaya untuk tetap menjaga kelestarian cagar budaya tersebut. Sehingga segala bentuk perlakuan terhadap kawasan ini pun harus diatur menjadi sebuah kebijakan dalam perangkat hukum yang disahkan oleh lembaga terkait dalam membuat dan melaksanakan peraturan yang dibuat. Hal tersebut tentunya harus mengacu dari prinsip - prinsip pelestarian cagar budaya.

7) Melakukan pembebasan lahan untuk pembangunan sarana penunjang aktivitas Kawasan Banten Lama seperti penyediaan ruang parkir yang terpusat, sentra $P K L$, pusat oleh - oleh, ruang terbuka hijau, panggung seni, toilet umum dan pusat informasi kawasan.

Kawasan Banten Lama yang mempunyai keperuntukan untuk wisata perlu mempunyai sarana penunjang untuk memperlancar jalannya aktivitas wisata yang ada. Saat ini, Kawasan Banten Lama disulitkan dalam segi lahan yang tersedia, tumpang tindihnya kepemilikan lahan yang ada dalam kawasan tersebut membuat pemerintah harus melakukan pembebasan lahan untuk pembangunan penunjang aktivitas kawasan seperti penyediaan ruang parkir yang terpusat, sentra penjualan untuk para PKL, pusat oleh oleh, ruang terbuka hijau, panggung seni, toilet umum dan pusat informasi kawasan. Diharapkan dengan adanya sarana tersebut, citra Kawasan Banten Lama akan kembali vital.

\section{KESIMPULAN}

Faktor - faktor turunnya vitalitas pada Kawasan Banten Lama memiliki keterkaitan satu sama dengan yang lain. Hal ini terlihat dari faktor ekonomi, faktor fisik, serta faktor kebudayaan yang mempunyai akar permasalahan dari faktor sosial dan faktor institusi. Hal ini dapat disimpulkan, faktor yang menjadikan turunnya vitalitas pada Kawasan Banten Lama ialah faktor sosial dan faktor institusi. Dua hal tersebut merupakan bagian yang penting dalam pengelolaan kawasan tersebut.

Kawasan Banten Lama mendapat posisi pada kuadran 4 yaitu Defense Strategy. Dimana posisi tersebut merupakan situasi yang sangat tidak menguntungkan yang menandakan Kawasan Banten Lama menghadapi kondisi yang lemah dan mempunyai tantangan besar. Kawasan Banten Lama dihadapkan dengan berbagai ancaman dan kelemahan internal. Dalam posisi tersebut strategi yang diambil yaitu faktor ancaman serta faktor kelemahan sehingga hasil dari matriks SWOT menunjukkan bahwa ada 7 strategi yang dapat diimplementasikan pada Kawasan Banten Lama yaitu, menjalin kerjasama antar pihak yang terkait, membuat arahan kerja secara teknis, mengadakan pelatihan edukasi mengenai pentingnya nilai kawasan, melakukan sosialisasi, melakukan pemberdayaan masyarakat dalam memanfaatkan potensi; sosial, ekonomi serta kebudayaan, membuat kebijakan pada kawasan, dan melakukan pembebasan lahan untuk pembangunan sarana penunjang aktivitas kawasan.

\section{DAFTAR PUSTAKA}

[1] H. Shirvani, The Urban Design Process. New York: Van Nostrand Reinhold, 1985.

[2] Badan Perencanaan Pembangunan Daerah Provinsi Banten, Rencana Detail Tata Ruang Wilayah Provinsi Banten Tahun 2010-2030. Badan Perencanaan Pembangunan Daerah Provinsi Banten, 2009.

[3] S. Julian, "Arahan pengembangan kawasan wisata bersejarah Banten Lama,” Universitas Brawijaya, 2008.

[4] Departemen Kimpraswil, Pedoman Umum Program Penataan dan Revitalisasi Kawasan. Jakarta: Departemen Wilayah Direktorat Jendral Tata Perkotaan dan Tata Pedesaan Jakarta, 2002.

[5] Dinas Bina Marga dan Tata Ruang PemProv Banten, Pengendalian Pemanfaatan Ruang Kawasan Strategis Provinsi Sudut Pandang SosBud Kawasan Banten Lama. Dinas Bina Marga dan Tata Ruang PemProv Banten, 2014.

[6] N. Muhadjir, Metodologi penelitian kualitatif: telaah positivistik rasionalistik, phenomenologik realisme metaphisik. Yogyakarta: Rake Serasin, 1990.

[7] J. J. Rooney and L. N. Vanden Heuvel, "Root cause analysis for Beginners,” Qual. Prog., vol. 37, no. 7, pp. 45-53, 2004.

[8] D. Rahmawati, "Penerapan Metode Rootcause Analysis (RCA) dalam Pengembangan Kawasan Wisata Cagar Budaya Kampung Kemasan Gresik, Surabaya,” J. Penataan Ruang, vol. 10, no. 1, 2016.

[9] F. Rangkuti, Analisis SWOT teknik membedah kasus bisnis. Jakarta: Gramedia Pustaka Utama, 2006. 